\title{
An Analytical Study Of The Nature And Issues Of Beggars In Karachi
}

\author{
Imrana Saeed Jamil \\ Women's Studies \\ University of Karachi \\ Nasreen Aslam Shah \\ Department of Social Work \& Women's Studies \\ University of Karachi \\ Siraj Bashir \\ Department of Social Work \\ University of Balochistan
}

\begin{abstract}
Begging is a phenomenon that attracts global attention, particularly when it comes to children, because of their vulnerability and negative side effects on their personalities. The age of a child places him/her at a disadvantage and one of the most humiliating profession for a child is begging. According to the defining characteristics of the ILO, child begging is a form of forced child labour. By using quantitative research method researcher has analyzed different factors and circumstances which these beggars are experiencing, and the universe of population for this study is chosen as metropolitan city Karachi of Sindh, Pakistan. Whereas, convenience and purposive sampling techniques of non-probability sampling method are used in order to collect the data by two hundred and sixteen (216) respondents from various areas of Karachi city. The current study focuses on the socio-economic issues related to girls and boys beggars living in Karachi. Beggar children beg on the streets, but they build some relationships with people whom they meet on a daily basis, e.g. shopkeepers, street vendors, criminals and etc. These relationships define their behaviour and attitude, which may be positive or negative and they get acquainted with them and get involved in different activities.
\end{abstract}

Keywords: Beggar Children, Unemployment, Poverty, Socio-Economic Problems.

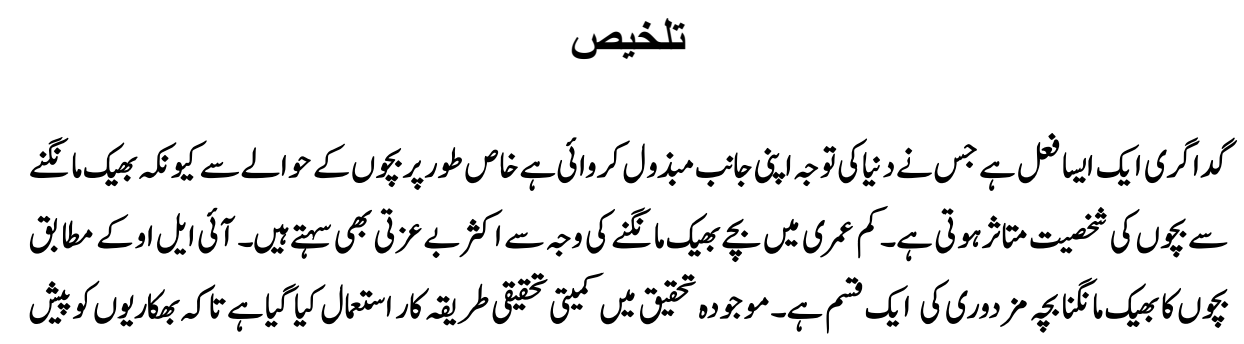




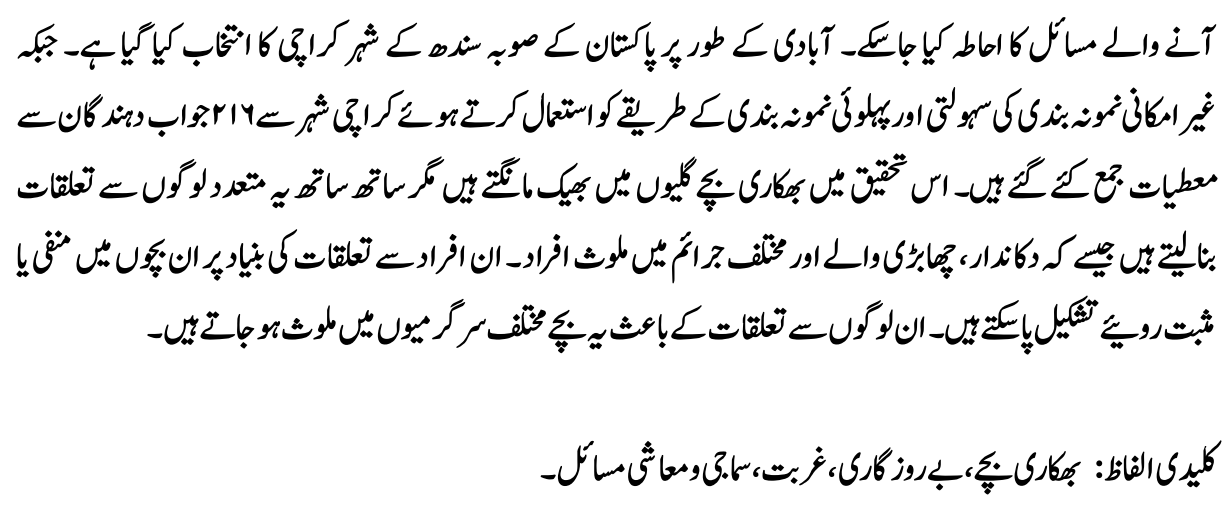

\section{Introduction}

Begging represents a very complex and intricate array of relationships and discourses. In general, this research has focused on beggar children who are one of the most vulnerable segment of the society. The emphasis is on their welfare, and the focal point of this study is the life of the children on the streets. Therefore, children who are involved in begging activities are mainly classified as street children and this is the worst forms of child labour (Save the Children, 2011). Though beggar children beg on the streets, but they build some relationships with people whom they meet on a daily basis, e.g. shopkeepers, street vendors, criminals and etc. These relationships define their behaviour and attitude, which may be positive or negative and they get acquainted with them and get involved in different activities (Weiss, 2007). In addition, only few researches have been conducted, but they have focused adult beggars only and child beggars have been totally ignored (Kassah, 2008).

Begging is a phenomenon that attracts global attention, particularly when it comes to children, because of their vulnerability and negative side effects on their personalities. The age of a child places him/her at a disadvantage and one of the most humiliating profession for a child is begging (Mace, 2016). The younger children are more vulnerable physically and psychologically than the older ones (Kaushik, 2014). A research conducted at international level reveals certain hazardous and difficult situations in which these children work as beggars (Nwazuoke \& Igwe, 2016). Surprisingly, despite all these difficulties which are associated with begging like humiliation and exploitation, the children continue to beg, because it is usually not their choice; therefore they have to continue to beg in order to earn money.

According to the defining characteristics of the ILO, child begging is a form of forced child labour (IPEC, 2015). Milne believes that the issue of begging is a global issue and none of the nation across the globe has found the effective solution of the problem yet (Milne, 2015). IPEC quoted that according to the estimates of the ILO, in 2012, around 
168 million children were involved in such inhumane form of work (IPEC, 2015). The majority of these children belong to third world countries and due to unemployment and poverty they are forced to adopt it as a profession and for having no choice they continue to beg at the cost of their childhood (Mace, 2016).

Many factors are considered as potential factors in enhancing the social evil of global child begging or begging at all, but the major factors are religion and poverty because it influences human behaviour (Zoumanigui, 2016). Bukoye reported that, when parents send their children for education away from home, then these children are sometimes forcefully incorporated into begging, some say that begging has taken the form of an industry now (Bukoye, 2015). Similarly, Magashi pointed out that among all the contributing factors of begging, poverty seems to be the most common and vibrant factor (Magashi, 2015). According to many national and international agencies and organizations believe that child begging can be referred as child abuse and it is a clear violation of child's rights. Some organizations strongly recommend that violation of child's rights lead to the exploitation of human rights as well. Every child has the right to enjoy childhood and to receive quality life by getting proper education, proper potential growth, physical and mental development, access to basic rights and having the liberty to make certain decisions on their own (UNICEF, 2004).

In 1989, after the enactment of the Convention on the Rights of the Child, the issue was raised at international level and the entire world realized the intensity of the issue. Though the issue gained the attention at the international level, but still no significant results are achieved yet. This is a complete policy document which is responsible for ensuring the safety of all children around the globe (Okyere \& Ansell, 2014). Article 18(b) of the Convention stipulates that the governments should assist parents in nurturing their children. Article 28(a) argues that the governments should provide free and basic compulsory education to every child, since it is their birth right. In addition, Article 32, states that governments have the obligation to defend children from economic burden and their engagement in hazardous forms of work, which can endanger their life, health and can deprive them from getting the education, besides that some other risks like harassment and abuse are also involved in harming them physically, mentally, psychologically, spiritually, morally or in their social development needed (UNICEF, 1989).

In July 1990, the African Charter on the Rights and Welfare of the Child (ACRWC) was approved, just after one year of the UN General Assembly Convention. Article 11 of the Charter stipulates that all children in African countries must participate in basic education, which should be free of charge by allowing children to actively participate in education without getting involved in economic activities. In addition, Article 15 states that children should be protected from any form of economic exploitation and they should not be engaged in hazardous forms of work, which may interfere with their physical, 
psychological, spiritual, moral or social development. Article 31 stipulates that African children are very respectful toward their parents and elders, and they protect and reinforce African traditional values in their relations with other community members (UNICEF, 1990). However, it must be noted that this article was only found in ACRWC, but it was not found in other child's rights documents.

Although children begging, is a kind of economic activity, wherein both boys and girls under 18 are begging, and mainly they go through physical and psychological oppression (Save the Children, 2011). UNICEF reported that, the worst thing is that $13 \%$ of beggar children are trafficked in South Eastern Europe, where they are incorporated into forced begging. Forced begging is usually imposed by family members, because children cannot deny what their parents ask them to do (Ryan, 2007). These children are left with no choice except fulfilling the bidding of their family members (Aronowitz, 2009). It is not only the parents who force them to beg, in fact, there is a begging mafia who use these children through the contract system for begging. Police has reported that there are gangs who kidnap children, either they train them as beggars or traffic them. The World Bank claims that this practice is very common in Europe, Latin America, South and Central Asia, Middle East, West Africa and the Caribbean countries (Nelen \& Siegel 2017). Some researchers have found that begging is a money making profession; in fact, easy money making type of work. Sometimes the contractor (thekedaar) gives incentives to those children who bring the heavy amount earned through begging to motivate them to bring more money.

UNICEF, reports that child beggars have no hope of their better future and they are not even aware of their rights, which cause exploitation to its extremes. Due to lack of awareness regarding health these children are prone to HIV infection also (Alayarian, 2017). Begging conditions expose these children to verbal and physical abuse, which includes: harassment and violence even by police. Human Rights Watch has shown that beggar children are exposed to the risks having no safety and shelter, food or health care. In addition, they become drug addicts or gets involved in criminal activities (Kaushik, 2014).

Poor families force their children to beg to earn money, because they are unable to feed them and to fulfill their needs. Beggar children are left alone to beg and they keep roaming all day on the streets and these streets are very cruel and dangerous for a child who cannot even protect himself (Pachauri, 1999), and these children face poverty, loneliness, sexual and physical abuse. They lack love, care, and protection. Government should sort these issues which are projecting our youth vulnerable to threats, which they are unable to recover from (Dabir \& Athale 2011). This could be possible only if the government takes effective measures and for that purpose, actual facts and figures should be conceived in order to develop adequate laws and policies. Unfortunately, we do not have systematic information regarding beggar boys and girls. 
Rather than looking for previous data, which is no more effective now, we should collect sex aggregated data based on new and circumstantial evidence in order to curb down the abusive relationship of various social elements with children. Media regularly publishes the current status of child related issues, for example, about child labour, child beggars and beggar mafia and their operational setup. They work in a very organized manner and uses children and adults as their labour force on the streets. Police system also needs amendments to make this law and order system more effective rather than supporting criminals they should facilitate the victims and this can be done easily by making effective policies and its strict implementation (Room, 1990). The stories of beggar mafia, which are published through the media, sometimes are organized and manipulated by the police. The media is mislead by police by giving false statements by saying that the children who are kidnapped and are used as beggars are already disabled, but on the other hand who has given them the right to abduct even disabled children and make their life more miserable (Aslam, 1995).

In Pakistan, people's views regarding beggars and begging are a combination of many aspects, like morality, religion, and social ethics. Civil society and the government have not studied the question thoroughly that who begs, why and under what conditions? People encourage them by giving money, especially on religious occasions and in the month of Ramadan; because it is a common thinking that this way we are giving Zakat or Alms and Charity. But these beggars are working as an employee for the contractor thus, this does not appear to be giving Zakat or Alms and Charity, we are actually promoting it in a way. Since beggars work in a network, therefore, they adopt ways to beg, which can melt our heart and we give away money instantly. Here we need to realize the fact that these people are working as mafia, they are not needy persons; in fact, they are stealing the right of needy people. Begging is potentially linked with an organized crime and illicit activities. Since these beggars work for the contractor (thekedaar); therefore, they cannot keep their earned amount to themselves; it is taken from them by their contractor (Shah, 2004).

Karachi is plagued by many social ills, among which beggary is a continuously increasing problem. The centre of activity for the beggary is the mosques, business areas and traffic signals. These beggars change their appearances to gain commiseration. There are people out there, who are really needy and they rely on charities. However, there is a group of professional beggars on the streets of the city, who frequently trouble people and sometimes they even paralyse the situation. According to reports, some beggar groups abduct children and make them disabled physically and leave them to beg on the streets. It has turned into a very profitable business. It is one of the most stigmatizing occupations, because they are humiliated and also face the embarrassment. It requires great audacity and patience to accept humiliation, hatred, insult and abuse by others and that too throughout the day and daily. They have become human parasites in society and they know very well how to play with 
their human psychology to gain their benefit. These guts and skills are transferred from generation to generation (Afzal, 2011). They know how to manipulate and stimulate emotions and get the most out of people. The current study focuses on the socio-economic issues related to girls and boys beggars living in Karachi.

\section{Review Literature}

Previously, the expression of beggar was linked with an individual who has entered into old age and undergoes certain physical sickness; they usually wear rags, dirty and smelly clothes. They maintain their filthy appearance with unshaved face and grubby physique (ACHPR, 2011). Previously the perception regarding beggars was that old and sick people usually beg to manage their life and due to sickness they are unable to earn money through work i.e., being economically weak they have no other choice than begging. As a result the society is considered responsible to provide better living to these powerless people without criticizing them. But people who beg even after being healthy are considered shameless; these perceptions portray the thinking of previous cultures from ancient societies. Other than old and powerless people, some young able bodied people are also engaged in begging (ACHPR, 2005).

In ancient times it was observed that men used to beg more than women, and if women were into begging then, they were supposed to accompany their male partner. This proves that in early societies men were idlers and they used to earn through begging. But in the present world a large number of young able bodied males and females both are involved in begging and they also adopt untidy appearance to gain sympathy by showing their muddy and grimy look (ACHPR, 2005).

\section{Street Begging in the Contemporary World}

In third world countries practices street begging and it is one of the oldest profession adopted by the powerless social element. Various researches have concluded that in third world countries begging is not considered as social ailment or odd profession. In fact, it is an urban practice globally, for example in United States, Mexico, Shangai in China and Johannesburg; South Africa (Arbeiter, 2007). In recent years in many cities of UK and India begging is a common phenomenon and is a profession of a huge number of poor populations. Like ancient societies street begging is not very common in the present societies and beggars are considered as worthless people (Ariong, 2016).

Unlike ancient societies the proportion of child beggars is constantly increasing, which was not the ancient scenario. Mothers in begging profession force their children to beg, because they earn more money than adults by seizing people's attention more than adults by gaining people's sympathy. Now begging has become more socialized and organized 
phenomena. Now they beggars beg in the form of large and organized groups unlike previous times. Contractors hire people to beg and earn money for them and they have fixed places where they beg separately or in groups (Atkinson, 2004).

\section{Reasons for Street Begging}

People get involved in begging due to many reasons; either they have a motive of their own or to support their families. They argue that they have no other option than begging to survive. People believe that giving money to these beggars is counted as giving charity, which is also a concept of Buddhism. That is giving money to needy people as alms in the form of food, money, clothes and other stuff. In Buddhism it is believed that man is born in rich or poor family without his/her choice therefore, it is not their fault. Thus, one should not treat them heartlessly and cannot send them without giving food or their required stuff, and if they do so then it is clearly mentioned that they commit sin by disgracing them. The Buddhism followers therefore, treat beggars kindly with tolerance (Bird, 2007).

In contemporary societies begging is not an acceptable profession and beggars are not seen as social fits. This perception has changed the social attitude towards beggars. These beggars are seen mostly around mosques, markets and public places. During holy month of Ramzan beggars seek to gain sympathy to earn more money. They try to exploit people at holy occasions to get alms and charity. No religion has ever allowed begging, it is always condemned. This attitude has raised many queries that why people adopt this profession when it is not accepted by the society. These questions show the social negligence towards the helpless and powerless people (Boateng, 1983).

The findings of various researches show that a large proportion of beggars are either handicapped or sick. Many people have varied perception that their illness cannot be a reason for them to beg, as many sick and handicapped people earn through work with honour. Therefore, the social idea is changed regarding the previous concepts of begging. Some studies have been carried out on child begging in Asia, Europe, South America and Africa (Chandra, 2005). The all-encompassing discourses in the literature point to how the privileges of these broods are abused which is connected to parental carelessness, poverty and looking for of holy information.

Children are overstated intellectually as a result of their connection in child labour or begging. Also in Africa, studies show progenies, notably between them are street children, who are beggars and whom the United Nation's International Children Emergency Fund (UNICEF), categorizes as "broods of the street" and "children on the street". The "progenies of the road" are those who beg in the streets all their life. They have no household associates and are consequently to fend for themselves on the roads by appealing in all kinds of unskilled jobs comprising begging. The "on the lane children" on the other hand, have sturdy family bonds and stay with their paternities who support their begging. Occasionally however, it is done out of the youngster's own decision all in 
an effort to complement the family's income (ILO/ACHPR, 2009). Whilst the NGOs and child rights activists do not favor the sending of the children by the parents for begging, the parents are of the opinion that they are performing in the best concern of the children. Even when illustrations are involved, scholars understand social standing of a child to unearth their furtive worlds. Still knowing such facts, a usual understanding is that there is not much research done on the subject (Institute for Intersectionality Research and Practice, 2012). The coping policies these child beggars trust upon to survive in spite of these difficulties have not been given much. Furthermore, there is a gap in the literature of a hypothetical description of what makes the beggar children cope and from the standpoint of Muslim children who are continuing with their parents (Jentoft, 2003).

\section{Theoretical Framework}

This study was framed within two theories namely childhood and social exclusion theories. The two theories were used to complement each other. They helped to illuminate issues under investigation and guided the study.

\section{Childhood Theory}

Johann Amos Comenius (1592-1670) and David Locke (1632-1704) created this theory and are called the founder of childhood theory. This theory identifies that the childhood age concept is socially constructed phenomenon, which can be differentiated on the basis of social, cultural and economic understandings. These theories actually focus on basic definition of childhood and the meanings of children (Bass, 2004), which includes: rights of children, access to education, protection against all odds and their respect as a child (James \& Pront, 1997). Whereas, Skovdal (2009) has also urged that to differentiate between good or normal child years in contrast to bad or abnormal child years we need to explore all its dimensions. And this idea is used to identify the perturbing circumstances of child beggars (Holland, 2009). A man is compelled to come into the regular limitations of incongruous and confusing tumult of impetuses, which occasionally evoke stiffness within the being. The researchers have clarified the life as reasonable and a willingness to move along successfully with an adverse impel that is a big challenge (Kabiza, 2017).

Every individual who is born in a society has to face certain difficulties although most of his needs are fulfilled. The difficulties of the individual are not the same and similar with others. It may overlap with each other depending upon their nature and profession etc. The beggars constitute the lowest strata of the society, and their problems are many and distressing. There problems differ from one another depending upon their age, health, sex, place of shelter, place of begging, mode of begging, income, expenditure, saving and socio-economic background, etc., as a whole. In the present study, information has been collected from the various categories of beggars regarding their problems which reveal the important aspect of their life. The problems of the able-bodied beggars are different from the problems of disabled and ill beggars which also include the lepers. Likewise, the problems of the street beggars who have no permanent place of shelter differ from the beggars residing in the colonies. A list of problems has been prepared in this study which the beggars. 
1. Physical and Biological problems.

2. Social' problems.

3. Economic and Financial problems

4. Problems of food

5. Problems of education

6. Political problems

7. Problems of housing \& accommodation.

8. Demographic problems

9. Psychological problems

10. Religious problems.

\section{Methodology}

Methodology is a process which is based on certain approaches and principles for doing something in a proper way, for example carrying out research from the initial stage. It is the process which is used for accumulating information and figures for the rationale of making final conclusion (Derniame, Kaba, \& Wastell, 1999). This study focuses on the emphasis is on the welfare of beggars, and the focal point of this study is the life of the children on the streets. Therefore, children who are involved in begging activities are mainly classified as street children and this is the worst forms of child labour. Therefore, the study focused on collecting data regarding their socio-economic issues by using quantitative research method in order to get accurate facts regarding the issue. Convenience and purposive sampling techniques of non-probability sampling method are used in order to collect the data by two hundred and sixteen respondents from many areas of Karachi city. Selected methodology is used to get the insight and exact situation about the socio-economic issues of beggars, to highlight the effects on their lives and its impact on their health.

\section{Results and Discussion}

This segment includes quantitative data and findings along with the discussion.

Table: 1

Distribution of respondents according to their age group

\begin{tabular}{|l|c|c|}
\hline Age in Years & Frequency & Percentage \\
\hline Less than 10 Years & 107 & $49.54 \%$ \\
\hline $11-14$ Years & 95 & $43.98 \%$ \\
\hline $15-18$ Years & 14 & $6.48 \%$ \\
\hline Total & $\mathbf{2 1 6}$ & $\mathbf{1 0 0 \%}$ \\
\hline
\end{tabular}

Data clearly shows the age of the respondents which says that $49.54 \%$ falls in the age group of less than 10 years, while $43.98 \%$ were in the category of $11-14$ years of age group, and $6.48 \%$ children falls in the category of $15-18$ years of age. This data shows that majority of the children who were engaged in begging falls in the category of less than 10 years. All 
of them were professional beggars and their entire family was engaged in earning through begging. There are many contributing factors which forced them for begging.

Table: 2

Distribution of respondents according to their gender

\begin{tabular}{|l|c|c|}
\hline Gender & Frequency & Percentage \\
\hline Boy Child & 165 & $76.3 \%$ \\
\hline Girl Child & 51 & $23.7 \%$ \\
\hline Total & $\mathbf{2 1 6}$ & $\mathbf{1 0 0 \%}$ \\
\hline
\end{tabular}

This data indicates the gender of the respondents which clearly states that $76.3 \%$ boy child whereas $23.7 \%$ were engaged in begging. They find no other way out except begging and earn something for themselves and for their families as well. They all were professionals and engaged in street begging.

Table: 3

Distribution of respondents according to their educational qualification

\begin{tabular}{|l|c|c|}
\hline Educational Qualification & Frequency & Percentage \\
\hline Illiterate & 181 & $83.80 \%$ \\
\hline Literate & 18 & $8.33 \%$ \\
\hline Madrasah (Religious Education) & 7 & $3.24 \%$ \\
\hline Primary & 9 & $4.17 \%$ \\
\hline Secondary & 1 & $0.46 \%$ \\
\hline Total & $\mathbf{2 1 6}$ & $\mathbf{1 0 0 \%}$ \\
\hline
\end{tabular}

In this table educational qualification of the respondents have revealed the fact that majority of them $(83.80 \%)$ were illiterate, whereas $8.33 \%$ were those who called themselves literate can read and write their names and read Urdu newspapers, $4.17 \%$ were primary pass, while $3.24 \%$ were going to madrasahs' for religious education, and according to $0.46 \%$ respondents they were secondary pass.

Table: 4

Distribution of respondents according to do you want to get education

\begin{tabular}{|l|c|c|}
\hline Do You Want to get Education & Frequency & Percentage \\
\hline Yes & 129 & $59.72 \%$ \\
\hline No & 87 & $40.28 \%$ \\
\hline Total & $\mathbf{2 1 6}$ & $\mathbf{1 0 0 \%}$ \\
\hline
\end{tabular}

While asking them about do they want to get education $59.72 \%$ respondents showed their interest in getting education but at the same time they do not want to give up begging as it is an easy way of earning money, while $40.28 \%$ were not interested in getting education 
at all as all of them belong to the poor families where education has no importance and do not think begging is a crime or social evil as well.

Table: 5

Distribution according to why do you think why people are begging so much

\begin{tabular}{|l|c|c|}
\hline Reasons of begging & Frequency & Percentage \\
\hline Due to poverty & 139 & $64.35 \%$ \\
\hline Due to un-employment & 25 & $11.57 \%$ \\
\hline No other opportunities for Survival & 33 & $15.27 \%$ \\
\hline Un-equal distribution of resources & 11 & $5.09 \%$ \\
\hline Social un-justice & 8 & $3.70 \%$ \\
\hline Total & $\mathbf{2 1 6}$ & $\mathbf{1 0 0 \%}$ \\
\hline
\end{tabular}

When asked them the reason that why people are begging so much data indicates that majority of the respondents i.e. $64.35 \%$ said that due to poverty people are forced to do begging as they have no other choice, they were illiterate and do not have any professional skills which helps them in getting any job so they found it easier to beg for fulfilling their day to day needs instead of doing any tedious and demanding labour work, whereas $15.27 \%$ respondents said that they found no other opportunities for their survival, $11.57 \%$ said that due to un-employment they started begging, while $5.09 \%$ said un-equal distribution of resources forced them to indulge in begging, and 3.70\% said that they saw social un-justice in every walk of life and find begging as a trouble-free and effort less work so they adopted begging as their profession.

Table: 6

Distribution according to what problems do you face during begging

\begin{tabular}{|l|c|c|}
\hline Problems Faced during begging & Frequency & Percentage \\
\hline Police stops from begging & 61 & $28.24 \%$ \\
\hline Face accident & 38 & $17.59 \%$ \\
\hline Transgender annoys us & 47 & $21.76 \%$ \\
\hline Face no problem & 19 & $8.80 \%$ \\
\hline Newcomers annoys & 11 & $5.09 \%$ \\
\hline Do not allow to come near shops & 28 & $12.96 \%$ \\
\hline People scolds & 6 & $2.88 \%$ \\
\hline People give less money & 6 & $2.88 \%$ \\
\hline Total & $\mathbf{2 1 6}$ & $\mathbf{1 0 0 \%}$ \\
\hline
\end{tabular}

Data has shown that while telling about their problems which they face during begging $28.24 \%$ respondents said that policeman stops them from begging and also asked them for bribes, $21.76 \%$ said that transgender also annoys them as on major streets, roundabout and signals they claimed their authority and said that it is their territory so they tease them to leave there are where they were begging, $17.59 \%$ respondents said that sometimes they faced accidents on streets or roundabout while chasing the cars for begging, $12.96 \%$ said that shopkeepers misbehaved with them and do not allow them to come near to their shops, $8.80 \%$ said that they never faced any sort of problems, while $5.09 \%$ sad that newcomers in this field also annoys them, and $2.88 \%$ each respondents 
said that people scolds them badly which as a human hurts them a lot and people also give them very less amount.

Table: 7

Distribution of respondents according to how much you earn daily through begging

\begin{tabular}{|l|c|c|}
\hline How Much You Earn through Begging & Frequency & Percentage \\
\hline Less than 100 Rs. & 30 & $13.89 \%$ \\
\hline $101-150$ Rs. & 31 & $14.35 \%$ \\
\hline $151-200$ Rs. & 56 & $25.93 \%$ \\
\hline $201-250$ Rs. & 35 & $16.20 \%$ \\
\hline More than 250 Rs. & 64 & $29.63 \%$ \\
\hline Total & $\mathbf{2 1 6}$ & $\mathbf{1 0 0 \%}$ \\
\hline
\end{tabular}

This table shows the earning trend of the beggars, it indicates that $29.63 \%$ of the respondents said that they earn more than 200 Rs. daily, 25.93\% said that they earn in between $151-200$ Rs. daily, $16.20 \%$ said that their daily earning is in between $201-250$ Rs. While $14.35 \%$ said that they get in betwwn $101-150$ Rs. On daily basis, and $13.89 \%$ earned less than 100 Rs. on daily basis.

Table: 8

Distribution according to your reaction in terms of no earning through begging

\begin{tabular}{|l|c|c|}
\hline $\begin{array}{l}\text { Your Reaction in Terms of No Earning } \\
\text { through Begging }\end{array}$ & Frequency & Percentage \\
\hline Curse people for not giving money & 72 & $33.33 \%$ \\
\hline Abuse them & 15 & $6.95 \%$ \\
\hline Spit on them & 6 & $2.78 \%$ \\
\hline Becomes aggressive & 81 & $37.5 \%$ \\
\hline Keep silent & 42 & $19.45 \%$ \\
\hline Total & $\mathbf{2 1 6}$ & $\mathbf{1 0 0 \%}$ \\
\hline
\end{tabular}

When asked the respondents about their reaction in terms of when they earn no money through begging, $37.5 \%$ said that they becomes aggressive when earn nothing in a day, $33.33 \%$ said that they started cursing people for not giving them money, while $19.45 \%$ said they keep silent what else they can do, 6.95\% said that they abuse the people who refused to give them money, and $2.78 \%$ said that they spit on them or on their vehicle when someone refused them for giving money.

Table: 9

Distribution according to in your opinion who earns more in begging boys or girls

\begin{tabular}{|l|c|c|}
\hline Who Earns More in Begging & Frequency & Percentage \\
\hline Boys & 86 & $39.81 \%$ \\
\hline Girls & 130 & $60.19 \%$ \\
\hline Total & $\mathbf{2 1 6}$ & $\mathbf{1 0 0 \%}$ \\
\hline
\end{tabular}


Data has revealed that while answering the question about who earns more in begging $60.19 \%$ respondents said that normally girls earn more in begging rather than boys while, $39.81 \%$ give their opinion that boys earn more money than girls in begging as they know the tricks how to grab their client and how to gain their sympathy.

Table: 10

Distribution according to how do you feel about this profession regarding peoples' attitude

\begin{tabular}{|l|c|c|}
\hline How Do You Feel & Frequency & Percentage \\
\hline Feel humiliation & 74 & $34.25 \%$ \\
\hline Feel ashamed & 36 & $16.16 \%$ \\
\hline Want to live a content life & 40 & $18.51 \%$ \\
\hline No respect in this society & 66 & $30.55 \%$ \\
\hline Total & $\mathbf{2 1 6}$ & $\mathbf{1 0 0 \%}$ \\
\hline
\end{tabular}

Data has shown the feeling of the respondents that $34.25 \%$ people said that they feel humiliation while people refused them or scolds them for not giving money, $30.55 \%$ said that society do not give them respect, while $18.51 \%$ said that they also want to live a content life, and $16.16 \%$ said that they feel ashamed when people abuse them or exploit them.

\section{Conclusions}

This research is a gender based analytical study which explains the nature and issues of beggars in the metropolitan city of Karachi. Major findings of the study highlights that majority of the beggars were less than of ten years old and $76.3 \%$ were boy child and majority of them which is $83.80 \%$ were illiterate. The findings of this study also reveal that due to poverty, un-employment, un-equal distribution of resources and unjust social behaviours forced them for begging because they do not find a respectable way out for them. People usually treat them very badly and use abusive language and scolds them while they asked them for money for their survival. There are multiple socio-economic factors which determine that how and when someone turns to begging, these factors limits their opportunities for progress. In Pakistan, popular perceptions of begging are linked with different moral and religious views and first-hand experience. None of the researches have developed deeply into the issue that who begs and why they beg, and what are the circumstances under which they forced to beg. Begging is seen as a sign of growing poverty or deprivation due to high inflation growth in the country, unemployment, but on the other hand potentially linked to growing street crime rates and illicit activities. It is generally accepted and understood that beggars work in groups and under organized mafia who not only exploits them but keep control on them because they are unable to keep their earnings for themselves. According to the research study conducted by SPARC in 2009 states that child begging is not only a result of poverty but it is an easy way of getting money, and parents usually from poor families forced their kids to adopt begging in urban areas specially in the mega cities like Karachi, Hyderabad, 
Sukkur, Lahore, these children are trained by their parents and mafia groups for earning money. They teach them the tricks that how to grab attention and seek sympathy of a common man. Karachi is a economic hub of Pakistan where people belong to all walks of life are living and earn their bread and butter. There might be some needy people who genuinely need and depends on charity, but there is a gang of professional beggars who are on the main streets and roundabouts of the city, creating all sorts of problems for people who often get irritated after being annoyed by these beggars. This study found that the main reason for begging was very low literacy rate, un-employment, day by day growing high inflation rate, low purchasing power, and prevailing un-just in the society. This study concludes that as these beggars are also humans who have their daily need, have also the right to live with respect and dignity, help these people to get education and get job in productive works as per their skills and potentials rather than abusing them, scolding them and giving them cash amount to get rid of them.

\section{Recommendations}

Following are the recommendations of this study:

1. Government should introduce effective education system for child beggars so that they can feed their families along with their education

2. State should monitor that no one can exploit children at any level and they could stop working as beggars.

3. State should regulate proper laws and policies for health and education of children on priority basis.

4. Work place laws and child protection laws should be implemented so that children especially girls cannot be exploited.

5. Government should formulate laws which can protect rights of children

6. Raising awareness of the illegitimacy of child beggars will also helps to curb down this activity. Parents should be made aware that forcing their children to work has legal consequences and that if they are found to assist and support the abuse, then the law will play its role.

\section{References}

ACHPR (2011). Concluding Observations of the African Commission on Human and Peoples Rights on the 4th Periodic Report of the Republic of Uganda. Available at http://www.achpr.org/files/sessions/49th/conc-obs/ $/{ }^{\text {th }} 20082010 /$ achpr49_conc_staterep4_uganda_2011_eng.pdf, Retrieved on $13^{\text {th }}$, November 2017.

ACHPR (2017). Working Group of Experts on Indigenous Populations/Communities. (2005). Report of the African Commission's Working Group of Experts on Indigenous Populations/Communities: Submitted in Accordance with the Resolution on the Rights of Indigenous Populations/Communities in Africa, 
$A C H P R$ and IWGIA, Available at https://www.iwgia.org/images/ publications//African_Commission_book.pdf

Alayarian, Aida (2017). Children of Refugees: Torture, Human Rights, and Psychological Consequences, Great Britain, KARNAC, p.106.

Arbeiter Samariter-Bund Deutschland. (2007). Final Summary Report: Monitoring and Psychosocial Support to Karimojong Children and Women in Kampiringisa Rehabilitation Center, Mpigi.

Ariong, S. (2016). Hunger kills 11 in Kaabong the Daily Monitor, Available at http://www.monitor.co.ug/News/National/Hunger-kills-11-inKaabong//688334/3088240/-/dye0o1z/-/index.html, Retrieved on 21st, November 2017.

Aronowitz, A. A. (2009). Human Trafficking, Human Misery: The Global Trade in Human Beings, London, Praeger, p. 81.

Aslam, S. (1995). Girl Child in Especially Difficult Circumstances, Islamabad, UNICEF, Available at https://www.files.ethz.ch/isn/45187/2004_WP22_A\% 20rapid\%20assessment\%20in\%20domestic\%20work.pdf

Atkinson, D. (2004). Research and empowerment: involving people with learning difficulties in oral and life history research. Disability \& Society, vol. 19(7), pp. 691-702.

Afzal, Anum (8 May, 2011). Professional Beggars in Karachi, Karachi, Pakistan, Dawn Publications, Available at https://www.dawn.com/news/627121.

Bass, L. E. (2004). Child Labour in Sub-Saharan Africa. London: Lynne Rienner, Boulder, p.6

Bird, S. (2007). Removing the Karamojong: A report for the MP of Bokora County Karamojaland, Hon Achia Terence. Available at http://www.travelartist.info/karamoja-article, Retrieved on 23rd, November 2017.

Boateng, F. (1983). African traditional education: A method of disseminating cultural values, Journal of Black Studies, vol. 13(3), pp. 321-336.

Bukoye, R. O. (2015). Case Study: Prevalence and Consequences of Streets Begging among Adults and Children in Nigeria, Procedia-Social and Behavioural Sciences, Vol. 171, pp. 323-333. 
Chandra, R. K. (2005). Indigenous Women: A Gender Perspective, Journal of Indigenous Peoples Rights, Vol. 1(2), pp. 34-39.

Dabir, N. \& Athale, N. (2011). From Street to Hope, New Delhi, Sage Publications, p. 94.

Holland, J. (2009). Young People and Social Capital: What Can It Do For Us? London: Families \& Social Capital Research Group, Young: Sage Journals, Vol. 17(4), pp. 331-350.

ILO/ACHPR. (2009). Country Report of the Research Project on the Constitutional and Legislative Protection of the Rights of Indigenous Peoples: Uganda. Available at http://www.chr.up.ac.za/chr_old/indigenous/country_reports/Country_ reports_Uganda .pdf. Retrieved on 25th, November 2017.

Institute for Intersectionality Research and Practice. (2012). Summary of themes. Dialogue on intersectionality and indigeneity, Available at https://www.academia.edu/4677649/Dialogue_On_Intersectionality_and_Indi geneity_Summary_of_Themes. Retrieved on 26th, November 2017.

IPEC (2015). World Report on Child Labour 2015: Paving the Way to Decent Work for Young People, http://www.ilo.org/ipec/Informationresources/WCMS358969/ lang--en/index.htm, Retrieved from 15 $5^{\text {th }}$, April 2016.

James, A. \& Pront, A. (1997). Constructing and Reconstructing Childhood. London: Falmer Press, p.49.

Jentoft, S. (2003). Co-management-the way forward, Fish and Fisheries Series, Vol. (26), pp. 1-16.

Kabiza Wilderness Safaris. (2017). Visiting the Karamojong People in KaramojaNortheastern Uganda. Available at http://kabiza.com/kabizawildernesssafaris/visiting-the-karamojong-people-in-karamoja-northeastern-uganda. Retrieved on 29th, November 2017.

Kassah, A. K. (2008). Begging as Work: A Study of People with Mobility Difficulties in Accra, Ghana, Disability and Society, vol.23:2, pp.163-170.

Kaushik, A. (2014). Rights of Children: A Case Study of Child Beggars at Public Places in India, Journal of Social Welfare and Human Rights, Vol. 2(1), pp.1-16. 
Mace, S. E. (2016). Global Threats to Child Safety, Paediatric Clinics of North America, Vol. 63(1), pp. 19-35.

Magashi, S. B. (2015). Education and the Right to Development of the Child in Northern Nigeria: A Proposal for Reforming the Almajiri Institute, Africa Today, Vol. 61(3), pp. 64-83.

Milne, B. (2015). Signed, Ratified but Not Implemented Rights of the Child, Switzerland, Springer International Publishing, p. 31.

Nelen, H. \& Siegel, D. (2017). Contemporary Organized Crime: Developments, Challenges, and Responses, Switzerland, Springer, p. 96.

Nwazuoke, A. N. \& Igwe, C. A. (2016). Worst Forms of Child Labour in Nigeria: An Appraisal of International and Local Legal Regimes, Beijing Law Review, Vol. 7(1), pp. 69-82.

Okyere, S., Imoh, A., \& Ansell, N. (2017). Children's Participation in Prohibited Work in Ghana and its Implications for the Convention on the Rights of the Child, Paper Presented at the Children's Lives in an Era of Children's Rights, Ghana, Africa, The Progress of the Convention on the Rights of the Child in Africa. Journal of Educational and Social Research, vol.7:3, pp.95-108.

Pachauri, S. K. (1999). Children and Human Rights, New Delhi, APH Publishing Corporation, p.100.

Room, G. (1990). Observatory on National Policies to Combat Social Exclusion. Synthesis Report. University of Bath, Commission of the European Communities Directorate General V Employment, Social Affairs and Industrial Relations p.13.

Ryan, L. (2007). Migrant Women, Social Networks and Motherhood: The Experiences of Irish Nurses in Britain, Sociology, vol.41:2, pp.295-312.

Save the Children (2011). Prevention of Child Exploitation in South East Europe: Regional Report on Child Begging, Prevalence, Prevention and Suppression of Child Begging, Norway, Save the children, Ministry of Foreign Affairs of the Kingdom of Norway, p.6.

Save the Children (2011). Regional Report on Child Begging: Prevalence, Prevention and Suppression of Child Begging, South East Asia, Safe the Children, Available at http://www.journals.aiac.org.au/index.php/IJELS/article/view /3102/2568. 
Shah, N. A. (2004). Beggar Girls of Karachi: A Survey, Karachi, University of Karachi, pp.15-17.

Skovdal, M. (2009). Young Carers in Western Kenya: Collective Struggles and Coping Strategies, London, London School of Economics and Political Science, Social Work, Oxford, Blackwell, p.378.

UNICEF (1989). The Convention on the Rights of the Child, New York, UNICEF, p.5.

UNICEF (1990). The African Charter on the Rights and Welfare of the Child, pp.3-4.

UNICEF (2004). Children Under Threat: The State of the Worlds Children 2005, New York, UNICEF, p.2.

Weiss, J. (2007). Begging and Almsgiving in Ghana: Muslims Positions towards Poverty and Distress, No, 133, Uppsala, Nordiska Afrikainstutet, p. 13.

Zoumanigui, A. K. (2016). On the Talibe Phenomenon: A Look into the Complex Nature of Forced Child Begging in Senegal, The International Journal of Children's Rights, Vol. 24(1), pp.185-203.

Imrana Saeed Jamil is Ph.D Scholar in the Centre of Excellence for Women's Studies, University of Karachi.

Dr. Nasreen Aslam Shah is Dean, Faculty of Arts and Social Sciences, University of Karachi, Meritorious Professor in the Department of Social Work and Director, Centre of Excellence for Women's Studies, University of Karachi.

Dr. Siraj Bashir is an Assistant Professor in the Department of Social Work, University of Balochistan, Quetta. 